\title{
An Empirical Study of the Teaching Mode of Scenarios Simulation in Business English under Verbal Behavior Theory
}

\author{
Jinyu Dong \\ Northeast Petroleum University, Daqing, Hei Longjiang Province, 163318, China
}

\begin{abstract}
With the rapid development of Chinese economy, the international cooperation become stronger and stronger. The business English Course has been offered in almost all the Chinese universities. Different from common English, Business English is a branch of ESP (English for Special Purpose), which is a kind of English usage under the pragmatic situation from the angle of the teaching content and teaching methods for meeting the actual needs of the learners. Business English is featured with high expertise and applicability, which purpose and practical value are clear and high. The traditional teaching methods can not follow the new trend and development of economic age. So the new teaching mode is needed deadly. The empirical study of the teaching mode of scenarios simulation in English to business English under verbal behavior theory is based on the analysis of the questionnaire and test by SPSS statistical method. Then the author made a conclusion that this mode is the most suitable teaching method of business English and is a good training pattern for multi-skilled talents who have positive energy.
\end{abstract}

Index Terms - verbal behavior, scenarios simulation in English, validity, empirical study

\section{INTRODUCTION}

\section{A. Introduction of Verbal Behavior Theory}

Verbal behavior is provided by psychologist B. F. Skinner (1957) who analyzes human behavior, encompassing what is traditionally called language, linguistics, or speech. For Skinner, verbal behavior is subject to the same controlling variables as any other operant behavior, although Skinner differentiates between verbal behavior which is mediated by other people and that which is mediated by the natural world. The book Verbal Behavior is almost entirely theoretical, involving little experimental research in the work itself. It was an outgrowth of series of lectures first presented at the University of Minnesota in the early 1940s and developed further in his summer lectures at Columbia and William James lectures at Harvard before the book's publication. A growing body of research and applications based on Verbal Behavior has occurred since its original publication, particularly in the past decade. In addition, a growing body of research has developed on structural topics in verbal behavior such as grammar.

The context of speaker utterances is central to Skinner's perspective on language. With this as a background, Skinner (1983) developed the premise that Verbal Behavior - behavior under the control of consequences mediated by other people (who can interchangeably function as speaker and listener) - was best understood in a functional analysis. This theoretical extension was a direct product of his basic research using what he referred to as the "three-term contingency model" with the basic behavioral unit being the response and its consequence in a specified situation (antecedent-behavior-consequence). This is now sometimes called the four-term contingency model with setting conditions added as a fourth term. This consists of a motivating operation, discriminative stimulus, response, and reinforcement. Skinner's Verbal Behavior also introduced the autoclitic and six elementary operants: mand, tact, audience relation, echoic, textual, and intraverbal. Skinner argued that verbal behavior is a function of the speaker's current environment and his past behavioral and genetic history. For Skinner, the proper object of study is behavior itself, analyzed without reference to hypothetical (mental) structures, but rather with reference to the functional relationships of the behavior in the environment in which it occurs. This analysis extends Ernst Mach's pragmatic inductive position in physics, and extends even further a disinclination towards hypothesis-making and testing. Verbal Behavior is divided into 5 parts with 19 chapters. The first chapter sets the stage for this work, a functional analysis of verbal behavior. Skinner presents verbal behavior as a function of controlling consequences and stimuli, not as the product of a special inherent capacity. Neither does he ask us to be satisfied with simply describing the structure, or patterns, of behavior. Skinner deals with some alternative, traditional formulations, and moves on to his own functional position.

\section{B. Definition of Business English}

As for Business English, some researches have been done a lot in this area. But the researchers can not reach an agreement on the definition of Business English until now because it involves both in General English and Special 
Purpose English.

As early as in the 1960s and 1970s, in order to distinguish business English from General English, the emphasis was put on business English vocabulary. So Ruth Moyer holds the view that "Business English is a study of English fundamentals which involves in grammar, punctuation, spelling, word usage, capitalization and so on, applied to sentences containing the vocabulary and concepts of business." Business English was simply viewed as general English plus business English vocabulary.

Many experts and scholars have defined different definitions of business English. With the expansion of economic activities and emergence of ESP, many scholars believe that Business English is a branch of ESP. Business English is classified into EGBP (English for General Business Purposes) and ESBP(English for Specific Business Purposes). But Business English differs from other varieties of ESP in that it is often a mix of specific content and general content. The former is usually related to a specific professional area while the latter is related to a general ability to make an effective communication in the business situation. However, business English is a kind of practical English, which involves not only general English, such as vocabulary, grammar, discourse, inter-cultural communication, but also economy, trade, finance, marketing, business, service. Business English is not special words in special grammar. It means "English used in the business context" (Jones \& Alexander, 2000, p7). Business English can not separate from the specific business context. According to that, we can say business English teaching can not leave business context.

Ever since China's entry into the WTO and its success in winning the bid to host 2008 Olympic Games, 2010 World Expo and 2010 Asian Games, China has been getting more and more integrated into the global village and economic globalization. Therefore, a higher demand of well-qualified, all-rounded international business talents with a good command of language and communication skills are urgently required. And then many universalities set up business English major.

\section{Limitation of Traditional Teaching Methods to Business English}

Even though Business English teaching has more than twenty years' history and many universities and colleges have set up Business English course, there are many problems existing in the teaching class of Business English. The teaching mode needs to be improved better and perfect the research of Business English teaching method.

First, the teaching in the class is centered on textbooks or language knowledge. Teachers put emphasis upon imparting theoretical knowledge rather than cultivating practical ability. Therefore, it deviates from the emphasis of class teaching. Some class teaching are partial to impart vocabulary and grammar in the business textbooks; some put stress on teaching business professional knowledge and concepts; some put the point on passing exams in order to get some Business English certificates. However, the practical capability does not get improved.

Second, Business English teaching makes use of the teaching link of General English teaching for the influence of traditional teaching thought. They often organize teaching, review old knowledge, impart new content, strengthen and make practice, make homework, etc. Language knowledge can only be practiced over and over in the non-context situation. Business English is a kind of applied language in the business situation where the business scene and language context are very important. Without the specific business situation, students can not master the skills of using language precisely. Even if the students can learn how to use language skill in the non-context situation, it is not easy for them to use language in the real business situation and the work environment.

Third, Business English teaching continues to use the teaching method of General English, putting much stress on teaching. The traditional teaching method includes lecture, discussion, demonstration, role-play and so on. Especially the lecture is used as the most common method. However, it also has some shortcomings. For example, its teaching goal is to acquire knowledge rather than master skill; the process of teaching must be involved with learners; materials are complex and numerous. From the quality of Business English, Business English teaching aims to develop students' ability to use English in the real business context. So it needs more knowledge involved in the teaching content and more practical methods used in the class.

Forth, a great progress has been made in the teaching tools, but in fact the tools are still backward. Because of lacking multimedia classroom, some Business English teachers still take use of the traditional teaching tools such as blackboard, chalk and recorder. In addition, some teachers can not master the cognition and usage of modern teaching technology, thus multimedia facilities can not be able to get full use.

Traditional teaching methods emphasize that teacher is the center as well as the leader in the class. Teachers are main speakers and they speak during the whole class. In the other side, students just only the listeners. And the teachers will talk about the business material in the textbook, for example, the language points, vocabulary, grammar, and structure of sentences. In the business class, the teachers always focus on the theories-teaching. They have never designed the practical plan, for example, group discussion and so on. Obviously, the traditional teaching methods is not a better mode to fit the new business English talent training mode. So we need a new mode deadly.

\section{Introduction of the Teaching Mode of Scenarios Simulation in English to Business English under Verbal Behavior Theory}

The teaching mode of scenarios simulation in English under verbal behavior theory to business English is developed from "the situation-based teaching mode". The situation-based teaching mode can be traced back to the Direct Method 
developed at the end of the nineteenth century as a revolution against the grammar-translation method. Practitioners of the Direct Method believe that language is learned best in a natural way by hearing words and sentences in the context and imitating what is heard. "Direct" here means associating meanings directly with the physical world — actions, objects, persons, situations, etc. — without translating or referring to the learners' mother tongue. In the classroom where the Direct Method is applied, only the target language is used and meanings are conveyed through showing, drawing, miming or demonstrating things. Great stress is placed on the oral practice of the target language by the question-answer exercises and conversation practices in which learners are encouraged to imitate and participate as much as possible.

Then the teaching mode of scenarios simulation in English is a better way in business English class. What is the meaning of the teaching mode of scenarios simulation in English? It means that students can communicate each other with English thought, analyze some cases and deal with some business issues by application of specific business situation and real business scenarios simulation in business English class. At the same time, both the teacher and students communicate each other only in English in the whole class, which can make some important and difficult business knowledge into students' deep memory. And students can grasp all kinds of business English skills. The teaching mode of scenarios simulation in English shown as the following diagram:

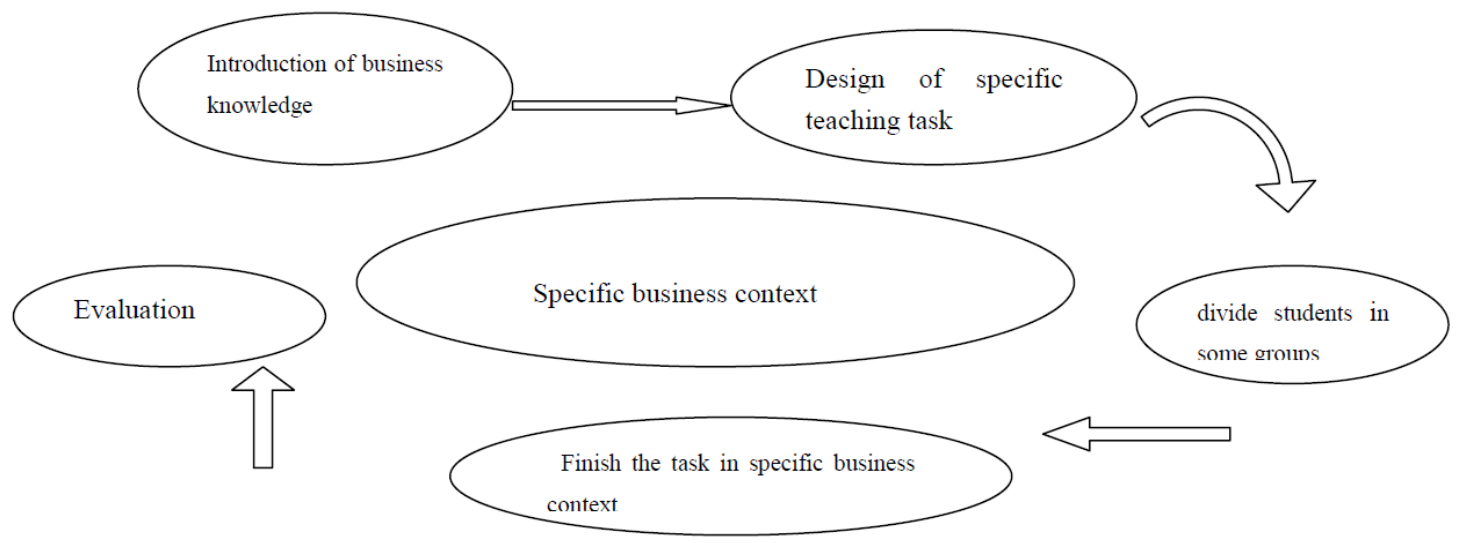

For example, specific business situation is that the production manager of a company has known that his component supplier had a financial crisis from the radio news. His company's production line will stop if he can not find better supplier until next Wednesday. Then design of task in the class: a. Contact with some suppliers by telephone, E-mail and fax to inquire the price; b. Choose the better suppliers according to their offers by analyzing their price, quality and reputation and so on; c. Negotiate with suppliers whom you selected. In this phase, divide all students into some teams, who act on a different role in the situation, such as purchase manager, general manager and sales representatives of supplier. d. Sign a contract according to the result of negotiation and form an agreement. Then report to the board or manager meeting and make a final decision. e. After the students finish the task, the teacher will evaluate all the teams' work and draw a conclusion. As last, notice: for all steps of the task including arranging the task, discussion and so on, the teacher and students must communicate with each other in English in the whole class.

The writer has designed an experiment of the teaching mode of scenarios simulation in English, and analyzed SPSS statistical theory and found that the mode can improve the students' abilities of creative business English.

\section{Design of the Teaching Mode of Scenarios Simulation In English to Business English Under Verbal BEHAVIOR THEORY: AN EXPERIMENT}

\section{A. The Experiment Purpose of the Teaching Mode of Scenarios Simulation in English}

The writer wants to investigate the effectiveness of the teaching mode of scenarios simulation in English to business English. So the writer does an experiment among her students in business English class and gets more useful information. There are 218 students from 8 classes taking part in both pre-test and post-test. Meanwhile, the writer designs a questionnaire which is about the teaching mode of scenarios simulation in English after experiment.

\section{B. The Experiment Subject of the Teaching Mode of Scenarios Simulation in English}

The subject involves in 218 students who major in English from 8 ordinary classes. All students are in the second semester of their third year. And all students are 17 to 19 years old. They have been studying business English and international business and trade in Chinese in the first semester of their third year. That is to say, they have some knowledge about business and business English. During the experiment, they have 16 weeks business English classes, and they will have gotten 4 credits by the end of the semester. All classes are experimental classes. The writer designed the experiment as two parts: one is the first semester, using traditional teaching mode, and using the final exam as 
pre-test. The other is the second semester, using scenarios simulation teaching mode, and using the final exam as post-test, then collecting and analyzing data to get the experiment result.

\section{The Experiment Steps of the Teaching Mode of Scenarios Simulation in English in Business English Class Time}

Now, we use 2 class periods as an example to talk the specific steps of experiment class. Teaching content is the same as the one that mentioned above: finding component suppliers. In class time, the teaching steps are in accordance with the five steps of the teaching mode of scenarios simulation in English. Specific teaching plan is shown as the following table:

\begin{tabular}{|c|c|c|c|c|}
\hline & Design of task & $\begin{array}{l}\text { Scenarios simulation } \\
\text { activities }\end{array}$ & Design students' teams & Time \\
\hline $\begin{array}{l}\text { The first class } \\
\text { period }\end{array}$ & $\begin{array}{l}\text { After listening to the news, the } \\
\text { students analyze the situation which } \\
\text { the supplier faced. Meanwhile,the } \\
\text { teacher will introduce some relevant } \\
\text { knowledge of esquire, offer and } \\
\text { business contract. }\end{array}$ & & All students & 20 munites \\
\hline $\begin{array}{l}\text { The first class } \\
\text { period }\end{array}$ & inquire to the suppliers & $\begin{array}{l}\text { Purchase department } \\
\text { meeting to discuss and } \\
\text { make a decision of some } \\
\text { items of inquire }\end{array}$ & $\begin{array}{l}\text { Divide the students into } 4 \text { teams. } \\
\text { There are } 6 \text { to } 7 \text { members in } \\
\text { each team. One of the teams is } \\
\text { purchase department, the other } \\
\text { three are different suppliers. }\end{array}$ & 15 munites \\
\hline $\begin{array}{l}\text { The first class } \\
\text { period }\end{array}$ & Offers of suppliers & $\begin{array}{l}\text { Suppliers teams discuss the } \\
\text { offer items. }\end{array}$ & $\begin{array}{l}\text { There are } 6 \text { to } 7 \text { members in } \\
\text { each team. One of teams is } \\
\text { purchase department, the other } \\
\text { three are different suppliers. }\end{array}$ & 10 munites \\
\hline $\begin{array}{l}\text { The second class } \\
\text { period }\end{array}$ & Negotiation and signing the contract & $\begin{array}{l}\text { Role-play: negotiating and } \\
\text { sign the contract at last. }\end{array}$ & $\begin{array}{l}\text { Four teams, there are } 6 \text { to } 7 \\
\text { members in each team. Two of } \\
\text { teams is purchase department, } \\
\text { the other two are different } \\
\text { suppliers. }\end{array}$ & 30 munites \\
\hline $\begin{array}{l}\text { The second class } \\
\text { period }\end{array}$ & $\begin{array}{l}\text { The teacher will evaluate all team's } \\
\text { work and draw a conclusion }\end{array}$ & & All students & 15 munites \\
\hline
\end{tabular}

\section{Collecting Data and Analyzing Result According to SPSS}

\section{Analyzing the result of business English level test}

All students who took part in the experiment have some business knowledge of business English. So before the experiment, we did pre-test of all students. And all students have taken part in the pre-test. The pre-test including four parts: listening, speaking, reading and writing. The total score is 100, including speaking test (40\%) and writing test $(60 \%)$. The analysis of the result data, analyzed by SPSS 13.0, is showed as the following table 1:

TABLE 1

\begin{tabular}{|l|l|l|l|l|}
\hline & Mean & N & Std. Deviation & Std Error Mean \\
\hline Writing & 77.50 & 208 & 8.576 & 0.821 \\
\hline Speaking & 69.21 & 208 & 8.431 & 0.806 \\
\hline Total & 74.18 & 208 & 7.773 & 0.654 \\
\hline
\end{tabular}

To show students' business English levels, post-test questions are designed by the same teacher as the pre-test. And the structure of scores are the same as pre-test, also the total score is 100 , including speaking test $(40 \%)$ and writing test $(60 \%)$, the result of post-past is showed as the following table 2:

TABLE 2

\begin{tabular}{|l|l|l|l|l|}
\hline & Mean & N & Std. Deviation & Std Error Mean \\
\hline Writing & 85.51 & 208 & 6.025 & 0.576 \\
\hline Speaking & 84.30 & 208 & 5.606 & 0.536 \\
\hline Total & 85.02 & 208 & 6.051 & 0.481 \\
\hline
\end{tabular}

From the table 1 and table 2, we can know easily that the writing average number (Mean) has increased from 77.50 to 85.51, the speaking (Mean) has increased from 69.21 to 84.30, and the total has increased from 74.18 to 85.02. According to that, we can learn students' abilities of all parts of business English have improved a lot after the experiment. To justify students' ability is superior to that before experiment, we analyze the data using SPSS 13.0 and the result is shown as table 3:

TABLE 3

\begin{tabular}{|l|l|l|l|l|l|}
\hline Contrast two tests & \multicolumn{2}{|l|}{ Contrast differences } & \multirow{2}{*}{ T } & \\
\hline & Mean & Std. Deviation & Std Error Mean & & \\
\hline Writing & 8.013 & 4.688 & 0.448 & -17.83 & .000 \\
\hline
\end{tabular}




\begin{tabular}{|l|l|l|l|l|l|}
\hline Speaking & 15.092 & 5.823 & 0.557 & -27.055 & .000 \\
\hline Total & 10.84 & 5.063 & 0.486 & -18.558 & .000 \\
\hline
\end{tabular}

According to table 3, the result is so clear, the T number is $-17.83,-27.055$ and -18.558 ; and Sig is $.000 \leq .05$.

Obviously, the result has justified that students have made a big progress in business English after the experiment. That is the teaching mode of scenarios simulation in English.

\section{Analyzing the result of the questionnaire}

To test and analyze the effectiveness of the teaching mode of scenarios simulation in English, we have designed a questionnaire, which can test the students interesting and abilities of business English ,including all kinds parts: traditional teaching mode, scenarios simulation teaching mode and so on. There are 10 questions of the questionnaire, and each question's answer includes 8 levels. All students (208 students) have taken part in the questionnaire investigation. The results are shown as table 4:

\begin{tabular}{|l|l|l|l|l|l|l|l|l|}
\hline Questions & $\begin{array}{l}\text { Like very } \\
\text { much }\end{array}$ & P & Like & P & Ok & P & Dislike & P \\
\hline $\begin{array}{l}\text { 1. Traditional teaching mode: the teacher is a leader } \\
\text { and introduces so much business and trade } \\
\text { knowledge. }\end{array}$ & 2 & 0.9 & 31 & 14.2 & 32 & 14.7 & 153 & 70.2 \\
\hline $\begin{array}{l}\text { 2. After teacher's introduction, the teacher asks some } \\
\text { questions to the students. Occasionally, discussion } \\
\text { mode is applied on the class }\end{array}$ & 5 & 2.2 & 12 & 4.6 & 23 & 10.6 & 178 & 81.7 \\
\hline $\begin{array}{l}\text { 3. The teacher communicates with students both in } \\
\text { Chinese and English. }\end{array}$ & 47 & 21.6 & 33 & 15.1 & 20 & 9.2 & 118 & 54.1 \\
\hline 4.The teacher communicates with students in English. & 125 & 57.3 & 35 & 16.1 & 36 & 16.5 & 22 & 10.1 \\
\hline $\begin{array}{l}\text { 5. The class mode of scenarios simulation in English } \\
\text { to analyze case. }\end{array}$ & 130 & 59.6 & 30 & 13.8 & 24 & 11 & 34 & 15.6 \\
\hline $\begin{array}{l}\text { 6.The class mode of scenarios simulation in English to } \\
\text { role play. }\end{array}$ & 189 & 86.7 & 12 & 5.5 & 11 & 5 & 6 & 2.8 \\
\hline 7. Group discussion in English & 182 & 83.5 & 15 & 6.9 & 0 & 0 & 21 & 9.6 \\
\hline $\begin{array}{l}\text { 8.The class mode of scenarios simulation in English to } \\
\text { show real business situation }\end{array}$ & 201 & 92.2 & 5 & 2.3 & 0 & 0 & 12 & 5.5 \\
\hline $\begin{array}{l}\text { 9.The class mode of scenarios simulation in English to } \\
\text { report. }\end{array}$ & 153 & 56.4 & 17 & 7.8 & 13 & 6.0 & 35 & 16.1 \\
\hline $\begin{array}{l}\text { 10. The class mode of teacher's evaluation and } \\
\text { conclusion in English. }\end{array}$ & 131 & 60.1 & 32 & 14.7 & 25 & 11.5 & 30 & 13.8 \\
\hline
\end{tabular}

From the table 4, we can find that obvious statistical data which shows the students who like all parts of the teaching mode of scenarios simulation in English very much are over 50\%. And the two questions: one is "the class mode of scenarios simulation in English to role play," and the other is "group discussion in English", the students like them very much over $80 \%$. From the result, we can know students like the mode, and at the same time the mode can stimulate students' interests and practise their abilities. Of course, there are $20 \%$ students like "the teacher communicate with students both in Chinese and English". But the reasons are that the students do not want to face the difficulties. We believe if we can insist on using the mode in business English class for a long time, all students can accept the mode and feel the benefits.

\section{CONCLUSION}

From the above analysis, we can know clearly that after almost one semester' experiment and practical use, students have made a great progress in every parts of business English, including speaking, listening, reading and writing, even interesting of business English. So we believe the teaching mode of scenarios simulation in English to business English class is better than traditional teaching mode which is "teacher is center, class is leader, text book is center". And the new mode can build the new teaching mode, that is, "students are leader, practice is leader, verbal behavior is leader". But we must think about some problems as following:

(1) The business English teachers must renew their knowledge continuously in order to provide the latest business English context. Today society is developing so quickly. For providing the advanced business knowledge and situation, the teacher must learn more and more, and renew more and more.

(2) The teachers must link more business situations, and link the key points to make students understood. This point is a high requirement of teachers. First, the teachers must find key points and difficult points before the class. Then , they must plan, organize and arrange the class task according to the specific business situation. So they can use the new mode effectively, and at the same time the key and difficult points are distinguished.

(3) The teachers must lead students to use English to solve all kinds of problems in business situations under society function and society culture.

All in all, with the application of the teaching mode of scenarios simulation in English to business English class, we can make students learn language points, practice language points and understand business knowledge. The mode can 
link the language learning and business theories. According to that, we can know that the mode can provide a better way to cultivate the creative business talents and the mode is the trend of business English.

\section{ACKNOWLEDGMENT}

This research was financially supported by Humanities and Social Sciences Foundation of Hei Longjiang Province-Analysis of Practical Business Foreign Language Talent Training Mode of New High Level Technology Development Zone in Hei Longjiang Province under Multielement.(Grant NO. 12532011)

\section{REFERENCES}

[1] Baum, William. (2004). Understanding Behaviorism: Behavior, Culture, and Evolution. Malden, MA: Wiley-Blackwell.

[2] Charles, Mitchell. (2001). International business culture. Shanghai: Shanghai International Studies University.

[3] Leo Jones, Richard Alexander. (2000). New international business English. Cambridge: Cambridge University.

[4] Skinner, Burrhus Frederick. (1957). Verbal Behavior. MA: Copley Publishing Group.

[5] Skinner, B.F. (1983). A Matter of Consequences. New York: Knopf.

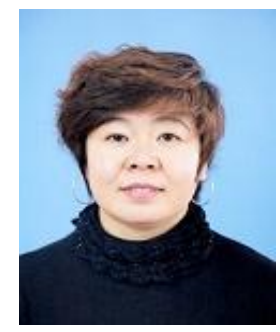

Jinyu Dong was born in Daqing, China in 1975. She received his Master degree in English Teaching from Harbin Normal University, China in 2013.

She is currently an associate professor in the School of Foreign Language, Northeast Petroleum University, Daqing, China. Her research interests include linguistics and business English teaching. 